\title{
Extraction of Elements from manganese nodules of CIOB through chemical partitioning
}

\author{
Barman, S.K. ${ }^{1}$, Tiwari, S.K. ${ }^{2}$ and Kumar, G. ${ }^{3}$ \\ ${ }^{1}$ Department of Geology, Institute of Science, Banaras Hindu University, Varanasi-221005, India, gmail: \\ barmansaurabh51@gmail.com \\ ${ }^{2}$ UGC-ASC (HRDC) \& Adjunct Faculty, Department of Geology, Institute of Science, Banaras Hindu \\ University, Varanasi-221005, India, gmail:sktiwari.bhu@gmail.com \\ ${ }^{3}$ Department of Geology, BIT Sindri, Dhanbad, India gmail: drgkumar12@gmail.com
}

\begin{abstract}
Polymetallic Nodules program of India aims at exploration and extraction of nodules from the Central Indian Ocean Basin (CIOB), having an area of 75,000 $\mathrm{km}^{2}$, located about $1600 \mathrm{~km}$ away from the southern tip of the Indian Peninsula. The samples are mainly obtained from the latitude $9.5^{\circ} \mathrm{S}$ to $12^{\circ} \mathrm{S}$ and longitude $87^{\circ} \mathrm{E}$ to $89.5^{\circ} \mathrm{E}$; water depth varying from $4,500-5,500 \mathrm{~m}$. Nodules are concretions on the sea bottom formed of concentric layers of iron and manganese hydroxides around a core. The core can be a small test (shell) of a microfossil (radiolarian or foraminifer), a phosphatized shark tooth, basalt debris or even fragments of earlier nodules ranging in size from 0.5 to $25 \mathrm{~cm}$ in diameter (average $2-4 \mathrm{~cm}$ ).
\end{abstract}

Manganese nodules occurring in beds of many of the world's oceans contain valuable metals such as $\mathrm{Cu}, \mathrm{Co}$, $\mathrm{Ni}, \mathrm{Mn}, \mathrm{Zn}$, etc. in the form of oxides -hydroxides. They contain mainly two intimately mixed metal oxides, namely manganese dioxide and hydrated iron oxide. In the present study about 30 samples have been studied, out of which 18 are in size class less than $4 \mathrm{~cm}$ and 12 are in more than $4 \mathrm{~cm}$. The samples show considerable higher values for metals like $\mathrm{Mn}, \mathrm{Ni}, \mathrm{Cu}, \mathrm{Co}$ and $\mathrm{Zn}$ and lower values for $\mathrm{Fe}, \mathrm{SiO}_{2}, \mathrm{Al}_{2} \mathrm{O}_{3}, \mathrm{TiO}_{2}$, and $\mathrm{P}_{2} \mathrm{O}_{5}$. The alkalise viz. $\mathrm{Na}_{2} \mathrm{O}, \mathrm{K}_{2} \mathrm{O}, \mathrm{MgO}$ also do not have very significant values. The study indicates that smaller nodules with rough surfaces have higher metal concentrations.

Rare earth metals (REE) and their compounds are in excessive demand now a days due to uses and applications in various electronics (semi/super conductors), medicine, ceramics and aerospace engineering sectors. Since total RE metal concentration is low, hence a suitable technology is urged to recover and enrich the total RE content from the deep sea nodules.

The present study includes the use of partition analysis to elucidate the distribution of elements between various coexisting phase of marine sediments and nodules. By comparing the composition of the various leach solutions from the selective chemical attacks, it is possible to differentiate the partition of elements between the various chemical fraction of the sediments and thus between its constituent phases. The technique of leaching includes: EDTA: Partitioning of trace elements in the recent marine sediments; $1 \mathrm{M} \mathrm{HCl}$ : to separate the iron oxide fraction of Fe-Mn nodules; Acetic Acid 25\% V/V: to separate detrital and non-detrital fraction of carbonates rocks; Acetic Acid $2.5 \%(\mathrm{~V} / \mathrm{V})$ : to separate the adsorbed Co ions from the lattice of clay minerals.

KEY WORD: REE, Manganese-nodule leached residues, $\delta-\mathrm{MnO}_{2}$, Oxide ores; $\mathrm{CH}_{3} \mathrm{COOH}$ leaching; hydroxylamine-HCL leaching; hydroxylamine-HCL $+\mathrm{CH}_{3} \mathrm{COOH}$ Leaching; HCL Leaching 